\title{
Historical Situations in Borges
}

\author{
\& \\ Daniel Balderston
}

$[\mathrm{H}]$ istory is not a text, not a narrative, but ... as an absent cause, it is inaccessible to us except in textual form, and ... our approach to it and to the Real itself necessarily passes through its prior textualization, its narrativization in the political unconscious ( Jameson 35)

Much of the critical work on Borges has been blinded by the notion that "Borges" is synonymous with irrealidad." The frequency and density of references to politics, history and everyday life have been glossed over or, even worse, neutralized by the common assertion that such references are part of a literary game. Borges's complex discussions of time have been reduced in much of the criticism to notions of circularity, though his major writings on the subject (including "Nueva refutación del tiempo," "El jardín de senderos que se bifurcan" and "El milagro secreto") assert that ideas of circular and nonlinear time are pleasant metaphysical diversions but that those who interest themselves in these notions are themselves mortal. ${ }^{2}$ Similarly, the constant references by Borges to

I I am thinking above all of the work of Barrenechea and Alazraki, from which so much of the subsequent criticism derives, but the same is certainly true for the works of Christ, Ferrer, Sturrock and many others. Oddly, those who make "universal" claims for Borges's writing are just as vehement about the lack of relations to reality as those who attack Borges for being escapist (such as those collected in the volume edited by Juan Fló).

2 I am referring to the end of the essay "Nueva refutacion del tiempo," in which Borges writes: "Negar la sucesión temporal, negar el yo, negar el universo astronómico, son desesperaciones aparentes y consuelos secretos. Nuestro destino (a diferencia del infierno de Swedenborg y del infierno de la mitología tibetana) no es espantoso por irreal; es espantoso porque es irreversible y de hierro. El tiempo es la sustancia de que estoy hecho. El tiempo es un río que me arrebata, pero yo soy el río; es un tigre que me destroza, pero yo soy el tigre; es un fuego que me consume, pero yo soy el fuego. El mundo, desgraciadamente, es real; yo, desgraciadamente, soy Borges" Obras completas 771). Although Borges here regards the existence of the universe as unfortunate, he nonetheless acknowledges its existence. 
history and politics have for the most part been oversimplified by those writing both for and against him. ${ }^{3}$ I propose to study here a few instances of the presence of historical and political material within the literary constructs of his stories, and show how the act of interpretation of those stories must take these matters into account, even at the risk of paradox.

In an essay that is widely considered Borges's most important (albeit extremely dense and arbitrary) statement on narrative theory, "La postulación de la realidad" (1931), he argues that one of the methods of creating verisimilitude in narrative "consiste en imaginar una realidad más compleja que la declarada al lector y referir sus derivaciones y efectos" (219), and that another involves the use of "pormenores lacónicos de larga proyección" (221). Both of these methods involve transgressing what formalist critics of whatever variety would consider the limits of the text, and ask the reader to consider the silences and unrealized implications of the text. This is in fact what Borges and his long-time collaborator, Adolfo Bioy Casares, themselves propose in the reported conversation at the beginning of "Tlön, Uqbar, Orbis Tertius":

Bioy Casares había cenado conmigo esa noche y nos demoró una vasta polémica sobre la ejecución de una novela en primera persona, cuyo narrador omitiera o desfigurara los hechos e incurriera en diversas contradicciones, que permitieran a unos pocos lectores-a muy pocos lectores-la adivinación de una realidad atroz o banal. (431)

Indeed, in "Tlön" itself such a horrible or banal reality can be glimpsed at the end of the story, when the narrator proposes to dedicate his days to an improbable Quevedian translation of Ume Buriall instead of attending to a world dominated by fascism, dialectical materialism and that new faith, Tlönism (443).

Sylvia Molloy has best analyzed the importance of the gaps (which she calls "hiatos") 4 in Borges's texts (and in the theory of

I I give several examples at the end of the article. One other, notable for the fervor of the argument against Borges's supposed "contradiccion de la historia," is Blas Matámoro's "Historia de Borges." See especially $136 \mathrm{ff}$.

${ }^{4}$ See especially 163-90. Molloy's concept of the narrative gap is rather more literal and pragmatic than Wolfgang Iser's almost metaphysical concept of the gap as "those very points at which the reader can enter the text, forming his [sic] own connections and conceptions and so creating the configurative meaning of what he [sic] is reading" (The Implied Reader 40). Despite the frequency of the use of the concept of "gap" in Iser's work, neither here nor in his subsequent The Act of Reading does he give a more precise definition of what he means by the term or how some other reader is to locate these gaps in a text. Molloy, in contrast, refers to very concrete details. She notes, for instance, that the first reference to the fantastic literature of Uqbar refers to the imaginary regions of Mlejnas and Tlön, and ob- 
narrative contained in them), though she has not explored very fully the historical and ideological implications of some of these gaps. What I propose to do here, in some detail with regard to "El jardín de senderos que se bifurcan" and then in a briefer fashion with "Pierre Menard," is to show how an imaginative reading of Borges's texts that is attentive to historical and political context can discover implications in those texts that considerably complicate the picture we have had up to now of the "postulation of reality" in Borges. ${ }^{5}$ The texts I have chosen have often been used in discussion of the fantastic or of self-conscious textuality. While I do not deny these elements of Borges's fiction, I would argue that the interest of the stories is considerably heightened by attention to the historical and political elements.

\section{1. “El jardín de senderos que se bifurcan"}

One of Borges's most famous stories, "El jardín de senderos que se bifurcan," plays on the conflict between two concepts of time, both of them linear: one, the ordinary concept of historical time, a single thread running from past to present and implying some variety of causality; the other, a notion of coexisting multiple threads of time, with a consequent loosening of the relations of cause and effect. Critics, most of them captivated by Stephen Albert's discourse on time as a "garden of forking paths," have privileged the second concept over the first, though in so doing they have slighted the rigorous temporal unities of the story and the importance of the historical references in it. I propose here to recover something of the historical specificity of the story ${ }^{6}$ by examining the role of one of the minor actors in it, Captain Richard Madden.

Before getting to Madden, though, and in order to show the degree to which the story is conceived in precise relation to historical events, I would like to mention not the obvious-the reference

serves that this passing reference to Mlejnas, never further elaborated in the text, tantalizes the reader in part by contrast to the dizzying complexities of the later references to Tlön (170).

${ }^{5}$ The strongest statement to date on the need to contextualize Borges's writings in the act of interpretation is Davi Arrigucci's essay on "Biografía de Tadeo Isidoro Cruz." See also my essay "The Mark of the Knife."

${ }^{6}$ I have already examined some of the same issues, though from a very different angle, in my article on the importance of the theme of war in the story. In that article I quote from some remarkable obfuscations by critics who seek to avoid the historical and material grounding of the story (see especially 92 ). 
to Liddell Hart's History of the World War-but two seemingly minor details. First, Yu Tsun's former place of employment. Borges, with his usually uncanny precision, ${ }^{7}$ has made him a former English teacher at the Hochschule of Tsingtao. Tsingtao and the surrounding province of Shantung was, as I have mentioned in my earlier article on this story, a German possession for fifteen years prior to the outbreak of the First World War. What makes the reference astonishingly accurate is that in 1909 a college was established in Tsingtao, the Deutsche-Chinesische Hochschule. The lower school of the Hochschule "provided a five-year course of study with a curriculum consisting of Chinese, German, English, mathematics, history, geography, science, hygiene, technical drawing, physical education, music, and stenography" (Schrecker 244). The German possessions in Tsingtao were seized by the Japanese in early November, 1914, but presumably by this time Yu Tsun was on his way to a new assignment in England.

The second element is the importance of the labyrinth in the story. Murillo observes that the labyrinth was not known to classical Chinese culture (259), but he does not complement that observation with a reference to the labyrinth that would establish the appropriateness of the image to the story. Eric J. Leed has written:

The image of the labyrinth appears again and again in reports of combatants not because of its inherent elegance, but because of its obviousness. It was a metaphor that suggested the fragmentary, disintegrated and disjunctive nature of the landscape traversed by the combatants of trench warfare. (78)

He then quotes from Charles Carrington's Subaltern's War, published in 1929:

When moving about in the trenches you turn a corner every few yards, which makes it seem like walking in a maze. It is impossible to keep your sense of direction and infinitely trying to proceed at all. When the trenches have been fought over the confusion becomes all the greater. Instead of neat, parallel trench lines, you make the best of existing

\footnotetext{
${ }^{7}$ Paul Fussell mentions Borges's reference to battlefield postcards-"vi a los sobrevivientes de una batalla, enviando tarjetas postales," in "El Aleph" (625-26)and comments that Borges "gets it profoundly right as usual" (183). We cannot know exactly what sources Borges had for such details about the First World War, though it should perhaps be remembered that he spent the years of the war in Switzerland and Spain with his family. Though I will cite an alarming variety of sources in what follows, there is nothing I mention that Borges could not have known about.
} 
trenches which might run in any direction other than the one you would prefer, until an old battlefield, like that of the Somme, became a labyrinth of trenches without any plan. (78)

The "old battlefield" of the Somme is the very one about which Yu Tsun is trying to send a message to Berlin. The veteran's reference to "a labyrinth of trenches without any plan" suggests that in addition to the allusions to the apocryphal Chinese novel (which could only by a leap of the imagination or the influence of the West refer to the labyrinth in any case, as Murillo has shown), the insistent labyrinth image in the story refers to the battlefields near the town of Albert in France. ${ }^{8}$ The degree of specificity in the story thus established, let us return to Madden.

The first information in Yu Tsun's manuscript, after the fragmentary initial sentence in which he hangs up the telephone, has to do with the voice that he has just recognized on the other end, the voice of Captain Richard Madden, speaking in German from the apartment of Viktor Runeberg. The voice signifies for $\mathrm{Yu}$ Tsun that Runeberg has been arrested or murdered (though the editor of his manuscript disagrees here, arguing that Madden killed Runeberg in self-defence). And Yu Tsun continues:

Madden era implacable. Mejor dicho, estaba obligado a ser implacable. Irlandés a las órdenes de Inglaterra, hombre acusado de tibieza y tal vez de traición, ėcómo no iba a abrazar y agradecer este milagroso favor: el descubrimiento, la captura, quizá la muerte, de dos agentes del Imperio Alemán? (472)

Madden will appear but twice more in the story: first, when $\mathrm{Yu}$ Tsun sees him trying to catch the train for Ashgrove, and at the end, when he rushes into Stephen Albert's house just after the death of the Sinologist. Yet his presence in the story is tantalizing (or I might say maddening), as we shall see.

The initial paragraph, with its slightly garbled reference to Liddell Hart's History of the World War 1914-1918, places the action of the story at the end of July, 1916. The reader who consults Liddell

\footnotetext{
${ }^{8}$ It has often been observed that early critics of the story repeat the mistaken assertion that Albert was in Belgium, not France. That mistake has now been cleared up thanks to the repeated references to Liddell Hart's History, which clearly shows the location of the town $(302,492,542)$. It is interesting now to wonder in retrospect why the confusion took hold in the first place. The strongest association between "Albert" and "Belgium" is not geographical but political: the king of the Belgians during the period of the world war was named Albert. There is thus some justification of an association between the ravaged country and the murdered British Sinologist.
} 
Hart's history (or who knows the history of the so-called Battle of the Somme in considerable detail) will discover that by error either of the author or of the printer the events should have been placed a month earlier, in late June, 1916 (see Murillo, Frank and Vosburg). In any case, the reader alert to Madden's drama will recognize the historical reference implicit in the accusation of treason against the British agent: the events of the story are taking place a mere two or three months after the failed Easter Rising in Dublin. Fifteen of the leaders of the rising, including the poet and political visionary Padraic $\mathrm{H}$. Pearse, had been executed by firing squad in the first days of May: it was in response to these events that Yeats was to write in September of the same year his memorable "Easter 1916," with its famous refrain "A terrible beauty is born." One of the charges at the secret court martial was that the Irish rebels had been part of a "German Conspiracy."9 Pearse addressed the court martial as follows:

I admit I was Commander-General, Commander-in-Chief of the forces of the Irish Republic which have been acting against you for the past week, and that I was President of the Provisional Government. I stand over all my acts and words done or spoken in these capacities ... First among all earthly things, as a boy and as a man, I have worked for Irish Freedom. I have helped organize, to arm, to train, and to discipline my fellow-countrymen to the sole end that, when the time came, they might fight for Irish freedom. The time, as it seemed to me, did come and we went into the fight. I am glad that we did, we seem to have lost, we have not lost. To refuse to fight would have been to lose, to fight is to win, we have kept faith with the past, and handed a tradition to the future ...

I repudiate the assertion of the prosecutor that I sought to aid and abet England's enemy. Germany is no more to me than England is. I asked [for] and accepted German aid in the shape of arms and expeditionary force, we neither asked for nor accepted German gold, nor had any traffic with Germany but what I state: my aim was to win Irish freedom: we struck the first blow ourselves ...

... If you strike us down now, we shall rise again and renew the fight. You cannot conquer Ireland; you cannot extinguish the Irish passion for freedom; if our deed has not been sufficient to win freedom, then our children will win it with a better deed. (Duff 191) ${ }^{10}$ 182.

9 For more details on the "German Conspiracy," see Dangerfield 155-61, 170,

${ }^{10}$ Pearse has been variously regarded as a saint and a poseur. For an assessment of his divided nature (and of his concept of blood sacrifice), see David Thornley. 
This speech is echoed in the story, oddly enough, by $\mathrm{Yu}$ Tsun, the German agent, when he explains his murder of Albert:

No lo hice por Alemania, no. Nada me importa un pais bárbaro, que me ha obligado a la abyección de ser un espía. Además, yo sé de un hombre de Inglaterra-un hombre modesto-que para mí no es menos que Goethe. Arriba de una hora no hablé con él, pero durante una hora fue Goethe ... Lo hice, porque yo sentía que el Jefe tenía en poco a los de mi raza - a los innumerables antepasados que confluyen en mí. Yo quería probarle que un amarillo podía salvar a sus ejércitos. (473)

Yu Tsun's stated motives - that he did it not for Germany but to vindicate his Chinese ancestors-echo Pearse's repudiation of Germany ("Germany is no more to me than England is") and celebration of his own national tradition. The celebration of ancestors is connected for both men with the vindication of a debased and colonized national identity, and with the founding or discovery of a tradition that will carry on into the future (or, as Yu Tsun would say after his conversation with Albert, into the innumerable futures). Since the story is centrally concerned with ancestry and the power of a surname, let us now return to Captain Richard Madden in the summer of 1916. I propose to look at a few of his ancestors, both historical and literary, and then to look at the story from the vantage point of Madden's dilemma.

Madden had two illustrious forebears in nineteenth-century letters: Sir Frederic Madden and Richard Robert Madden. As far as I have been able to determine, they were not related to one another, though both were British writers of Irish ancestry. Sir Frederic, whom the Encyclopaedia Britannica terms "perhaps the first palaeographer of his day" (17: 280), was the editor of a great number of Latin, Old and Middle English texts including Sir Gawain and the Green Knight, Pearl, Layamon's Brut, the Wycliffite Bible, Havelok the Dane, and others, as well as the translator of Silvestre's Paléographie universelle. He also wrote a diary in forty-three volumes, which A. N. L. Munby called "the most fascinating unpublished book I know" (Ackerman 73). His biographers state that "he may fairly be said to have set the canons of what we regard today as responsible editorial scholarship" (Ackerman ix), and add that due to the wealth of documentation we can learn more about Sir Frederic Madden "of what it is important to know than we can about almost any other person of similar consequence in the cen- 
tury" (Ackerman 41). He worked for most of his professional life in the British Library. One of his most significant works was his edition of Layamon's Brut, or Chronicle of Britain, a task which involved the collation of two manuscripts, one of them partially destroyed, and he pioneered a new technique for reconstructing and reading damaged parchment. The Silvestre book on universal paleography which Madden translated and edited includes chapters on Chinese and other Oriental writing systems; among Madden's unpublished works are some notes on Oriental paleography, and on the writing and language of Oriental nations (Ackerman 79). It seems evident enough from this description that the portrait of Stephen Albert in the Borges story is drawn in large measure on Sir Frederic Madden. One interesting feature of Sir Frederic Madden's academic career, given his Irish heritage (Ackerman 3, also mentioned in article in Encyclopaedia Britannica), is his apparent lack of interest in medieval Irish literature, though the Brut is in large measure a chronicle of Celtic Britain prior to the arrival of the Anglo-Saxons. Though Sir Frederic Madden devoted himself to a career of letters, his father and brothers were military men, that is, Irishmen in the service of the English crown, rather like their later descendant.

The other major mid-nineteenth century Madden, Richard Robert Madden, was more associated with Irish culture, and one of his many works was a two-volume History of Irish Periodical Literature. In the preface to that work, Captain Madden's namesake writes:

For my part I do not think there is any country in Europe in which it is more desirable to foster and encourage, to patronize and protect, literary tastes and intellectual recreations than Ireland, unhappily circumstanced as that country is, the great bulk of the food and the property of the land being transmitted to another-the former consumed, and the latter spent in a foreign land; without a resident nobility and gentry, the natural patrons in every independent country of literature, art, and science. (1:7)

Richard Madden adds that the "'English Pale' Government, planted in Ireland, differed not materially from the colonial English rule of the planters in the West Indies" (1: 13), an observation that doubtless serves to connect his writings on Ireland with his writings on Caribbean slavery. He closes his preface with the observation that, though the work is "purely and simply literary" 
in design (1: 81), and for that reason he desired "to abstain from the introduction into it of politics and polemics" (1: 82), yet he was unable to do so: "The progress of literature is so mixed up with that of civilization, and the interests of the latter are so interwoven with those of liberty-civil and religious - that the writer who deals with one subject, must of necessity take the other into consideration" (1: 82). ${ }^{11}$ This Madden is most important to Latin American letters because of his mission to the Caribbean. Edward Mullen writes that Madden was "an Irish physician who was employed by the British Colonial office from 1833 to 1839 in Jamaica and Cuba. Madden, a prolific writer and humanitarian, produced in his lifetime no fewer than forty volumes of writings on topics ranging from literature to medicine" (5). During his period in Cuba, when he was encharged with trying to end Spanish and North American involvement in the slave trade, Madden became closely linked to the group of Cuban abolitionist writers that met in the home of Domingo del Monte, a group that included Cirilo Villaverde and Anselmo Suárez y Romero. It was there that Madden made the acquaintance of the black poet Juan Francisco Manzano, who was soon persuaded by the abolitionist group to write an autobiography. ${ }^{12}$ Madden's translation of Manzano's autobiography, Life of the Negro Poet, Written by Himself. And Translated from the Spanish by R.R.M. was published in English in 1840; the original Spanish remained unpublished until 1937, though Manzano's life was to serve as inspiration for Suárez y Romero's sentimental novel Francisco in 1839 and of course more recently for the Cuban film El otro Francisco (1975), a film in which Madden appears as a character in the abolitionist tertulia. ${ }^{13}$

If Captain Richard Madden was related to this namesake, then, his English superiors would have reason to suspect his loyalty to the Crown, particularly in the volatile period just after the Easter Rising: the earlier Madden had been unequivocally pro-Irish and firmly opposed to colonialism and slavery. ${ }^{14}$ It seems almost uncanny that the critique of the theory of superior and inferior races,

\footnotetext{
"Madden also considers the relations between literature and society in his prefaces to A Memoir of the Literary Life and Correspondence of the Countess of Blessington (1: 1-2) and to his Life and Martyrdom of Savonarola (1: vi-vii).

${ }_{12}$ See Sylvia Molloy's article on Manzano's autobiography, especially 404-7.

13 See also Madden's own account of his stay in Cuba, in his Memoirs (74-85).

14 However, in the preface to The United Irishmen Madden writes: "We have outlived the wrongs that made rebels of these men" (1: xii).
} 
central to Madden's writings on slavery, ${ }^{15}$ should reappear in a cryptic form in the Borges story, in which both $\mathrm{Yu}$ Tsun and Madden are serving despised colonial masters, at once seeking to prove the abilities (read: equality) of their race at the same time that by their actions they reinforce the position of the colonial masters.

The third Madden I would like to discuss here figures in no dictionary of national biography, and enters the history of literature as the momentary alias of a character in a novel, one of Borges's favorite novels as it happens and (as I have argued elsewhere: El precursor velado 135-49) a crucial text for the understanding of the development of his crime fiction. In The Wrecker, co-authored in 1891 by Robert Louis Stevenson and his stepson Lloyd Osbourne, the narrator, an American sculptor named Loudon Dodd, overhears half of a telephone conversation between a shady San Francisco lawyer who has been trying to buy the wreck of a ship on Midway Island and the person he is representing. He then calls the same number himself from the Occidental Hotel in San Francisco and hears "a voice with the English sing-song - the voice plainly of a gentleman" (177). The narrator asks the unseen voice on the telephone "Why do you want to buy the Flying Scud?" (177), and receives no reply, though he imagines to himself "the picture of a man with a telephone dice-box to his ear, and at the small voice of a single question, struck suddenly as white as ashes" (177). Two hundred pages later, after an extraordinary odyssey around the world which serves only to muddle the question, he sits in Barbizon, in the forest of Fontainebleau in France, across the table from an Englishman who is going by the name of Madden, and after identifying himself as one of the people who bought the ship, he asks:

"One question more," said I. "Did you recognize my voice?"

"Your voice?" he repeated. "How should I? I had never heard it-we have never met."

"And yet, we have been in conversation before now," said I, "and I asked you a question which you never answered, and which I have since had many thousand better reasons for putting to myself."

He turned suddenly white. "Good God!" he cried, "are you the man in the telephone?"

${ }^{15}$ See for example the several essays, including a most interesting one on Father Las Casas, appended to the life of Manzano (Mullen 168-205). 
I nodded.

"Well, well!" said he. "It would take a good deal of magnanimity to forgive you that. What nights I have passed! That little whisper has whistled in my ear ever since, like the wind in a keyhole. ..." (385)

The brief telephone conversation between Dodd and MaddenCarthew is one of the earliest telephone conversations in literature. For John Brooks, in "The First and Only Century of Telephone Literature" (1977), ${ }^{16}$ the most significant examples of telephone conversations in literature are in Joyce's Ulysses and Proust's $R e$ cherche; the incident from The Wrecker is a striking early example of the motif because of the insistence on the disquieting ambiguity of the disembodied voice. The interrupted telephone conversation with which "El jardín de senderos" begins would seem clearly to refer back to the Stevenson-Osbourne novel, not only because of the presence of the same surname but also of the importance of the motifs of friendship and betrayal in both works, and the presence in them of murders which are motivated by a grisly kind of rationality rather than by hatred.

The last of the Maddens I would like to mention here is one whose existence I have been able to confirm, though data is rather scarce. Nonetheless, his relevance to my argument is obvious enough, so I will at least mention him in passing. In 1939, Josef von Sternberg, Borges's favorite director of the late twenties and early thirties, made a now forgotten film Sergeant Madden. This film, released just three years before the composition of the Borges story, was a vehicle for Wallace Beery, who tended to play professional Irishmen. The brief synopsis of the film in Nash and Ross's The Motion Picture Guide reads as follows:

A long-drawn-out tale with just enough plot twists to make it interesting. Beery is the typical Irish policeman who is the pride of the force and plays strictly by the book. His boy Curtis also becomes a policeman, but is more interested in getting promoted than he is in being a good cop. His attitude turns off many of his fellow cops, and when he shoots a kid caught stealing, he's set up and sent to prison. Prison does not rehabilitate him, but rather makes him worse. He escapes and goes on a robbery binge. A trap is set for him at the hospital where his son has just

${ }^{16}$ Brooks does not discuss the Stevenson example in this article or in his booklength study of the history of the telephone. In the book, however, he does quote from a Stevenson article in 1889 in which the Scottish writer complains of the telephone as an invasion of privacy (95). 
been born. Setting the trap is his father, who places justice ahead of his own blood. (7: 2824) ${ }^{17}$

The Madden of the Borges story could not have known in 1916 that more than twenty years later a film would be made about yet another member of his family, so I will not attempt to draw this Sergeant Madden into Captain Richard Madden's family romance, but of course the author of the story, who presumably knew of the other Maddens because of his encyclopedic knowledge of late nineteenth-century British culture, may have spurred on by the recently released Sternberg film to invent a prehistory for the Irish cop in New York City, a prehistory that would serve to link him (and Borges's own character) back to the illustrious Maddens of the previous century. In any case, it is interesting to note in the Sternberg film the renewed presence of the motifs of exile, treachery and of a conflict between two moralities (one based on family or colonized nationality, the other on the higher claims of empire or moral law).

All of our Maddens, then, the two Richards (Borges's captain and the abolitionist), Sir Frederic, the Madden also known as Carthew and Goddedaal, and the character in the Sternberg film are linked to the worlds of both arms and letters, and the two Richards in particular are passionately involved with the Irish question (though they are seemingly on different sides of that question). It is worth remarking that the arms and letters debate, and the matters of racial superiority and of colonialism, are all central concerns of $\mathrm{Yu}$ Tsun, and are reflected in the work of his illustrious ancestor Ts'ui Pen. It is on hearing the two versions of the chapter from the Garden of Forking Paths that Yu Tsun remarks: "sentí a mi alrededor y en mi oscuro cuerpo una invisible, intangible pululación. No la pululación de los divergentes, paralelos y finalmente coalescentes ejércitos, sino una agitación más inaccesible, más íntima y que ellos de algún modo prefiguraban" (478). A bit later in the story, Yu Tsun further states: "Volví a sentir esa pululación de que hablé. Me pareció que el húmedo jardín que rodeaba la casa estaba saturado hasta lo infinito de invisibles personas. Esas personas eran Albert y yo, secretos, atareados y multiformes en otras dimensiones del tiempo" (479). If $\mathrm{Yu}$ Tsun is at once the Chinese spy and a student in the Hung Lu Meng

\footnotetext{
${ }^{17}$ Nash and Ross take the plot summary from the longer review of the film that appeared in Variety in 1939.
} 
or Dream of the Red Chamber, as various critics have noticed (Murillo, Ferrer, Balderston), it is surely just as significant that $\mathrm{Yu}$ Tsun's other double, his implacable enemy Madden, should exist in the secret, busy multiplicity of time and of letters. In the summer of 1916, a few short months after the Easter Rising and the death of the fifteen Irish nationalist leaders, could he have been hoping to imitate the example of his abolitionist namesake or the busy paleographer? Did he perhaps recognize the disembodied voice on the other end of the telephone line as that of a student in an eighteenth-century Chinese novel, or remark on his own uncanny relation to a character in a mystery novel published twenty-five years earlier? Did he recognize himself in his ancestors as does $\mathrm{Yu}$ Tsun? Implacable, did he (like Yu Tsun) hope to "imponerse un porvenir que sea irrevocable como el pasado" (474), only to conclude that time, though irrevocable and beyond recovery, is also infinite in its variety and multiplicity?

\section{2. "Pierre Menard, autor del Quijote"}

The narrator tells us that Pierre Menard's Quijote was inspired by two texts "de valor desigual" (446). The first is the Novalis fragment on the total identification of reader and writer. ${ }^{18}$ The other text is: "uno de esos libros parasitarios que sitúan a Cristo en un bulevar, a Hamlet en la Cannebière o a don Quijote en Wall Street" (446). This evident reference to Joyce's Ulysses, which Borges had read and translated a section of soon after the novel was originally published in Paris, situates the writing of Menard's Quijote between the date of publication of the Joyce novel (1922) and the date of the writing of the obituary of Menard by his friend the narrator (Nîmes, 1939). The period between the world wars was of course a rich moment in French culture, and it will be my task here to clarify the relations between Menard's work and its context.

That said, I would like to proceed in the most outrageous

${ }^{18}$ Fragment 2005 in the Dresden edition bears the title "Pflichtenlehre des Lesers." It reads as follows: "Nur dann zeig' ich, dass ich einen Schriftsteller verstanden habe, wenn ich in seinem Geiste handeln kann; wenn ich ihn, ohne seine Individualität zu schmälern, übersetzen und mannigfach verändern kann." See also fragment 2006, "Der wahre Leser." 
fashion possible, and therefore propose that we examine chapters 9, 22 and 38 of Pierre Menard's Quijote. Since that book has unfortunately not been preserved (except for twenty-nine words from the ninth chapter), it will be necessary to reconstruct the text from that of Cervantes's El ingenioso hidalgo don Quijote de la Mancha, following the archeological metaphor proposed in the story (450).

Chapter 9 of Menard's Quijote includes the famous sentence on "la verdad, madre de la historia" that Menard rewrote under the tutelage of William James. It also contains an anxious reflection on literary modernity - don Quijote's library included modern books so perforce "su historia debía de ser moderna" (92)-and a passing reference to Freud and other "sabios, como de molde, que no solamente escribían sus hechos, sino que pintaban sus más mínimos pensamientos y niñerías, por más escondidas que fuesen" (92). Menard makes a telling remark on his own useless labor, that of rewriting an already existent book, when he says that "aun a mí no se me deben negar [respetos], por el trabajo y diligencia que puse en buscar el fin desta agradable historia" (93). It is also in this chapter that Menard mentions the manuscript of Cide Hamete Benegeli: "Otras algunas menudencias había que advertir, pero todas son de poca importancia y que no hacen al caso a la verdadera relación de la historia, que ninguna es mala como sea verdadera" (95). Here, he expresses the same sceptical approach to historical truth as that summarized by the narrator of the story in the words: "La verdad histórica, para él, no es lo que sucedió, es lo que juzgamos que sucedió" (449).

Chapter 22, the adventure of the galley slaves, was written by Menard only in part. It is easy to guess which part it is, though, given Menard's anxiety of influence. It is in this chapter that don Quijote meets up for the first time with Ginés de Pasamonte, who informs him that he has written his own life's story "por estos pulgares" (208) and compares his version with that of other examples of the picaresque genre. When don Quijote asks whether the book is finished, Ginés answers: " ¿Cómo puede estar acabado ... si aún no está acabada mi vida? Lo que está escrito es desde mi nacimiento hasta el punto que esta última vez me han echado en galeras" (209). We recognize Menard's self-reflexive irony here, as well as his sense of the fragmentation that literature and time suffer in the modern world.

The most important of the three chapters for my argument here is chapter 38, the discourse on arms and letters. The narrator of 
the Borges story comments that the decision in favor of arms is justifiable in Cervantes (or in Quevedo), but more difficult to understand in Menard: " $i$ Pero que el don Quijote de Pierre Menard - hombre contemporáneo de La trahison des clercs y de Bertrand Russell-reincida en esas nebulosas sofisterías!" (449). Modern pacifism came into being as we know it around the time of the First World War, first in the writings of Tolstoy, William James ("The Moral Equivalent of War," 1912) and Gandhi, then notably in the writings of Romain Rolland (published in English as Above the Battle in 1916) and of Bertrand Russell, who spent some time in prison in Britain because of his opposition to militarism. The period after the war were marked by the notable pacifist writings of Erich Maria Remarque (Im Westem nichts Neues, 1929) and of Aldous Huxley (Ends and Means, 1932) and by the pacifist resolution of the Students' Union at Oxford in 1933. Julien Benda's book La Trahison des clercs, published in 1927, became something of a cause célebre at the time (though not to the same extent as Rolland's essays published during the war). In the book Benda argues that the intellectual (the "clerc" of his title) must strive for a voice that is free of nationalism and xenophobia, even at the risk of conflict with his ${ }^{19}$ society. At the same time, he argues for something akin to the idea of socially committed writing and thought developed some years later by Sartre. The final chapter of the book is largely concerned with pacifism, both with a critique by Benda of what he calls "vulgar" and "mystical pacifism" (226-28) and a yearning for what he terms a more "realistic" pacifism (242), one which is born of the realization that the next war will mean the destruction of all human values.

Now, what does Menard have to say about the role of the intellectual in a conflict-ridden world? One curious aspect of the discourse he composes for Don Quijote is that he almost ignores the claims of the pacifist intellectual. He recognizes as a "laberinto de muy dificultosa salida" (392) the fact that soldiers are more expensive to keep than intellectuals because the latter can be rewarded with jobs while the former "no se pueden premiar sino con la mesma hacienda del señor a quien sirven" (392). A further labyrinth is the debate between arms and letters about which is more necessary:

19 I use the masculine possessive advisedly. It seems most unlikely that Benda contemplated women intellectuals playing such roles in society. 
dicen las letras que sin ellas no se podrían sustentar las armas, porque la guerra también tiene sus leyes y está sujeta a ellas, y que las leyes caen debajo de lo que son letras y letrados. A esto responden las armas que las leyes no se podrán sustentar sin ellas ... (392)

In words that must have been written in the difficult decade of the 1930s rather than in the more optimistic 20s, Menard adds:

porque con las armas se defienden las repúblicas, se conservan los reinos, se guardan las ciudades, se aseguran los caminos, se despejan los mares de cosarios, y finalmente, si por ellas no fuese, las repúblicas, los reinos, las monarquías, las ciudades, los caminos de mar y tierra estarían sujetos al rigor y a la confusión que trae consigo la guerra el tiempo que dura y tiene licencia de usar de sus previlegios y de sus fuerzas. (392)

Most of the rest of the discourse has to do with the danger faced by the soldier, a danger the intellectual supposedly does not face (though Menard could not have been thinking here of Lorca or Freud or Benjamin or Babel): He laments that warfare itself has changed in modern times, particularly with the development of artillery, which he calls a "diabólica invención," (393), though he neglects to mention such other diabolic inventions as the machine gun or mustard gas, which surely contributed as much to taking away the ancient nobility of the profession of war. Menard's Quijote, then, expresses a naive love of warfare for its own sake, an attitude quite out of tune with the intellectual currents of the day except - and the qualification gives one pause - for the nationalist intellectuals in the fascist countries of the 1930s. It is perhaps Menard's ultimate irony, dying as he does on the eve of the Second World War, that his knight errant should be enthusiastic about modern war much in the fashion of Marinetti or Wyndham Lewis. One presumes that in the lost latter part of his novel he shows the "Knight of the Sad Countenance" disabused of these warlike enthusiasms.

\section{Coda, not Conclusion}

I could of course continue forever in this vein. Hladík in modern Prague, Kilpatrick in Ireland in 1824, Qaholom in Mesoamerica just after the Spanish Conquest, David Alexander Glencairn in British India: Borges's stories abound in their precise references to historical situations. Some critics, however, have complained that 
the historical situations of the kind mentioned here are mere pretexts not to be taken seriously. Thus John Sturrock says of the initial reference to Liddell Hart in "El jardín de senderos que se bifurcan," "I have not checked this quotation because it does not matter in the least whether it is accurate; Borges needs a datum point and he has provided himself with one" (191), while Jean Franco has written that Borges removes causality from history (69). Similarly, R. K. Britton argues that Borges transmutes "history into literature and thence into myth" (612). In all of these assessments, history is fragmented, providing Borges with loose elements on which to found his fictions, and obviously by implication history is subordinated to literature. What I have been suggesting here is in fact quite the opposite: that history often becomes in Borges that "more complex reality" the existence of which is implied - and required - by the literary text.

Indeed, Borges's conception of history is not as close to that of Hayden White, for whom history is discourse, as to that of Fredric Jameson, for whom history is not narrative or textual, but an Other only partially recoverable to us in textual form. ${ }^{20}$ So, for example, in his poem "El otro tigre" Borges suggests that the writer's attempt to refer to something is an endless, and constantly frustrated, process. Borges evokes the images of tigers in books, describes tigers he remembers, imagines tigers in the jungle, yet the tiger is irreducibly other: there is always " $\mathrm{El}$ otro tigre, el que no está en el verso" (825). Perhaps the relation of literature to history is something like this.

What I have been doing here will no doubt seem arbitrary or mischievous to some. Indeed I would not be upset by such an assessment. Yet, as Borges eloquently argues in "La supersticiosa ética del lector," only transgressive readings can rescue our classics from the universe of dead letters. Since Borges is a notoriously

20 See my epigraph from The Political Unconscious (35), and also page 82 of the same book. I doubt, however, that the sort of reading I have done is quite what Jameson had in mind when he exhorts the critic: "Always historicize!" (9). His only reference to Borges in this work is a note that reads as follows: "The motif of treason, in particular, often expresses the classical anxiety of intellectuals at their 'free-floating' status and their lack of organic links with one or the other of the fundamental social classes: this reflexive meaning is explicit in Sartre, but implicit only in writers like Conrad or Borges ..." (258). There is of course an explicit link in Borges between the motif of treason and the position of the intellectual in society: the reference to Benda's La Trahison des clercs (an anticipation of the Sartrean position) in "Pierre Menard, autor del Quijote." 
self-conscious writer, it is hard to write about him without repeating what is already present in his texts (without "incurring in a tautology," to echo Pierre Menard). The free (some would say crazy) use I make of the historical and political references most definitely breaks us out of the vicious hermeneutic circle, moving us from mere "explications de texte" toward the study of textual implications. ${ }^{21}$

Tulane University

\section{WORKS CITED}

Ackerman, Robert W. and Gretchen P. Ackerman. Sir Frederic Madden: A Biographical Sketch and Bibliography. New York: Garland, 1979.

Alazraki, Jaime. La prosa narrativa de Jorge Luis Borges. Temas. Estilo. Madrid: Gredos, 1968.

Arrigucci Jr., Davi. 'Da fama e da infâmia (Borges no contexto literário latinoamericano." Boletim Bibliográfico Biblioteca Mário de Andrade 45.1-4 (1984): 67-90.

Balderston, Daniel. “' $\mathrm{El}$ jardín de senderos que se bifurcan': un cuento de la guerra." Perspectives on Contemporary Literature 14 (1988): 90-96.

- The Literary Universe of Jorge Luis Borges: An Index to References and Allusions to Persons, Titles, and Places in His Writings. Westport, Connecticut: Greenwood Press, 1986.

- "The Mark of the Knife: Scars as Signs in Borges." Modern Language Review 83.1 (1988): 67-75.

- El precursor velado: R. L. Stevenson en la obra de Borges. Buenos Aires: Editorial Sudamericana, 1985.

Barrenechea, Ana María. La expresión de la irrealidad en la obra de Jorge Luis Borges. 2nd ed. Buenos Aires: Editorial Paidós, 1967.

Benda, Julien. La Trahison des clercs. Paris: Editions Bernard Grasset, 1927.

Borges, Jorge Luis. Obras completas. Buenos Aires: Emecé, 1974.

Britton, R. K. "History, Myth, and Archetype in Borges's View of Argentina." Modern Language Review 74.3 (1979): 607-16.

Brooks, John. "The First and Only Century of Telephone Literature." The Social Impact of the Telephone. Ed. Ithiel de Sola Pool. Cambridge: MIT Press, 1977. 208-24.

- Telephone: The First Hundred Years. New York: Harper \& Row, 1976.

Cervantes, Miguel de. Don Quijote de la Mancha. Ed. Martín de Riquer. Barcelona: Editorial Juventud, 1968.

Christ, Ronald. The Narrow Act; Borges' Art of Allusion. New York: New York University Press, 1969.

21 This article is part of a larger project on Borges's uses of reality, which grows out of my earlier work on an index to Borges (The Literary Universe of Jorge Luis Borges, 1986). As such, I have but suggested here some lines of inquiry to be taken up later on. 
Dangerfield, George. The Damnable Question: A Study in Anglo-Irish Relations. Boston: Little, Brown and Company, 1976.

Duff, Charles. Six Days to Shake an Empire. South Brunswick: A. S. Barnes, 1966.

Ferrer, Manuel. Borges y la nada. London: Támesis, 1971.

Flo, Juan. Contra Borges. Buenos Aires: Galerna, 1978.

Franco, Jean. "The Utopia of a Tired Man: Jorge Luis Borges." Social Text 2.1 (1981): 52-78.

Frank, Roslyn M. and Nancy Vosburg. "Textos y contra-textos en 'El jardín de senderos que se bifurcan.' " Revista Iberoamericana 100-101 (1977): 517-34.

Fussell, Paul. The Great War and Modern Memory. New York: Oxford University Press, 1975.

Iser, Wolfgang. The Act of Reading: A Theory of Aesthetic Response. Baltimore: Johns Hopkins University Press, 1978.

The Implied Reader: Patterns of Communication in Prose Fiction from Bunyan to Beckett. Baltimore: Johns Hopkins University Press, 1974.

Jameson, Fredric. The Political Unconscious: Narrative as a Socially Symbolic Act. Ithaca: Cornell University Press, 1981.

Leed, Eric J. No Man's Land: Combat $\mathcal{S}^{2}$ Identity in World War I. Cambridge: Cambridge University Press, 1979.

Liddell Hart, Basil Henry. A History of the World War 1914-1918. 2nd enlarged ed. London: Faber \& Faber, 1934.

Madden, Richard Robert. The History of Irish Periodical Literature. 2 vols. London: T. C. Newby, 1867. Rpt. ed. New York: Johnson Reprint Corporation, 1968.

-The Life and Martyrdom of Savonarola, Illustrative of the History of Church and State Connexion. 2 vols. London: Thomas Cautley Newby, 1853.

The Literary Life and Correspondence of the Countess of Blessington. 2 vols. New York: Harper \& Brothers, 1855.

- Memoirs of Dr. R. R. Madden. Ed. T. More Madden. London: n. pub., 1891.

. The United Irishmen, Their Life and Times. 2 vols. London: J. Madden \& Co., 1842.

"Madden, Sir Frederic." Encyclopaedia Brilannica. 11th ed. New York: Encyclopaedia Britannica Company, 1911. 17: 280.

Matamoro, Blas. "Historia de Borges." Cuadernos Hispanoamericanos 424 (1985): 129-48.

Molloy, Sylvia. "From Serf to Self: The Autobiography of Juan Francisco Manzano." $M L N 104.2$ (1989): 393-417.

—. Las letras de Borges. Buenos Aires: Editorial Sudamericana, 1979.

Mullen, Edward J., ed. The Life and Poems of a Cuban Slave: Juan Francisco Manzano 1797-1854. Hamden: Archon Books, 1981.

Murillo, L. A. The Cyclical Night: Irony in James Joyce and Jorge Luis Borges. Cambridge: Harvard University Press, 1968.

Nash, Jay Robert and Stanley Ralph Ross. "Sergeant Madden." The Motion Picture Guide. Chicago: Cinebook, Inc., 1987. 7: 2824.

Novalis. Fragmente. Ed. Ernst Kamnitzer. Dresden: Wolfgang Jess Verlag, 1929.

Rolland, Romain. Above the Battle. Trans. C. K. Ogden. Chicago: Open Court Publishing Company, 1916.

Schrecker, John E. Imperialism and Chinese Nationalism: Germany in Shantung. Cambridge: Harvard University Press, 1971. 
“Sergeant Madden." Variety Film Reviews, 22 March 1939 (New York: Garland, 1983), n. p.

Stevenson, Robert Louis and Lloyd Osbourne. The Wrecker. Vol. 10 of Thistle Edition of Stevenson's Works. New York: Charles Scribner's Sons, 1902.

Sturrock, John. Paper Tigers: The Ideal Fictions of Jorge Luis Borges. Oxford: Clarendon Press, 1977.

Thornley, David. "Patrick Pearse - the Evolution of a Republican." Leaders and Men of the Easter Rising: Dublin 1916. Ed. F. X. Martin. Ithaca: Cornell University Press, 1967. 151-63. 